J. Dairy Sci. 99:9353-9353

http://dx.doi.org/10.3168/jds.2016-99-11-9353

(C) American Dairy Science Association ${ }^{\circledR}, 2016$.

\title{
Corrigendum to "Secretion of glucagon-like peptide-2 responds to nutrient intake but not glucose provision in milk-fed calves" (J. Dairy Sci. 99:5793-5807)
}

\section{J. J. Castro, S. Y. Morrison, A. Hosseinni, J. J. Loor, J. K. Drackley, and I. R. Ipharraguerre}

Two contributors were omitted from the authorship of this article. Jens Juul Holst and Bolette Hartmann (both from The NNF Center for Basic Metabolic Research and Department of Biomedical Sciences, Faculty of Health Sciences, University of Copenhagen, and The Panum Institute, Copenhagen, Denmark) should be included.

The authors regret the error.

\section{REFERENCES}

Castro, J. J., S. Y. Morrison, A. Hosseinni, J. J. Loor, J. K. Drackley, and I. R. Ipharraguerre. 2016. Secretion of glucagon-like peptide-2 responds to nutrient intake but not glucose provision in milk-fed calves. J. Dairy Sci. 99(7):5793-5807. 